39 Selten JP, Veen ND, Hoek HW, Laan W, Schols D, van der Tweel I, et al. Early course of schizophrenia in a representative Dutch incidence cohort. Schizophr Res 2007; 97: 79-87.

40 Rupp C, Fletcher E. A five to ten year follow-up study of 641 schizophrenic cases. Am J Psychiatry 1940; 96: 877-88.

41 Achte $\mathrm{K}$. On prognosis and rehabilitation in schizophrenic and paranoid psychoses: a comparative follow-up study of two series of patients first admitted to hospital in 1950 and 1960 respectively. Acta Psychiatr Scand 1967; 43: 9-217.

42 Scully PJ, Coakley G, Kinsella A, Waddington JL. Psychopathology, executive (frontal) and general cognitive impairment in relation to duration of initially untreated versus subsequently treated psychosis in chronic schizophrenia. Psychol Med 1997; 27: 1303-10.
43 Jeppesen $\mathrm{P}$, Petersen $\mathrm{L}$, Thorup A, Abel MB, Øhlenschlaeger J, Christensen TO, et al. The association between pre-morbid adjustment, duration of untreated psychosis and outcome in first-episode psychosis. Psychol Med 2008; 38: 1157-66.

44 Petersen L, Thorup A, Øqhlenschlaeger J, Christensen TØ, Jeppesen $\mathrm{P}$ Krarup G, et al. Predictors of remission and recovery in a first-episode schizophrenia spectrum disorder sample: 2-year follow-up of the OPUS trial. Can J Psychiatry 2008; 53: 660-70.

45 Tomotake M. Quality of life and its predictors in people with schizophrenia. J Med Invest 2011; 58: 167-74.

46 Thorup A, Petersen L, Jeppesen $\mathrm{P}$, Nordentoft M. The quality of life among first-episode psychotic patients in the OPUS trial. Schizophr Res 2010; 116 $27-34$.

\section{psychiatry and sacred texts}

\title{
Symeon the Holy Fool: patron of the mentally ill
}

\section{Fernando Espí Forcén and Carlos Espí Forcén}

Every professional guild or social group has always had a patron saint. That of the mentally ill is Symeon Salus (the fool), whose hagiography - the life of a saint - shares some symptoms of madness that gained him the patronage of this particular group. Symeon was an anchorite who was reportedly born in the city of Edessa, Syria in the 6th century AD. His life was dramatised in the 7th century as Life and conduct of Abba Symeon Called the Fool for the Sake of Christ written in Greek by Leontius of Neapolis (on Cyprus). Even if it is probably based on some biographical details narrated in the 6th-century Ecclesiastical History by Evagrius Scholasticus, the story of Symeon must be considered an original work of Leontius.

Like other ancient anchorites such as Symeon Stylite or Saint Anthony Abbot, he committed to a long period of retirement with his friend John At a certain point Symeon Salus felt the call from God to save human souls in a very particular way: he purportedly chose to look insane and moved to the city of Emesa. Before arriving in the city, he found a dead dog in a dunghill; he loosened the rope of his tunic, tied a dog's paw with it and dragged the carcass on the floor as he was entering the gates of the city. some children nearby saw him and cried 'Hey, a crazy monk', they ran after him and boxed him on the ears. The following day, which was a Sunday, symeon went to church and started cracking nuts noisily. After that, he

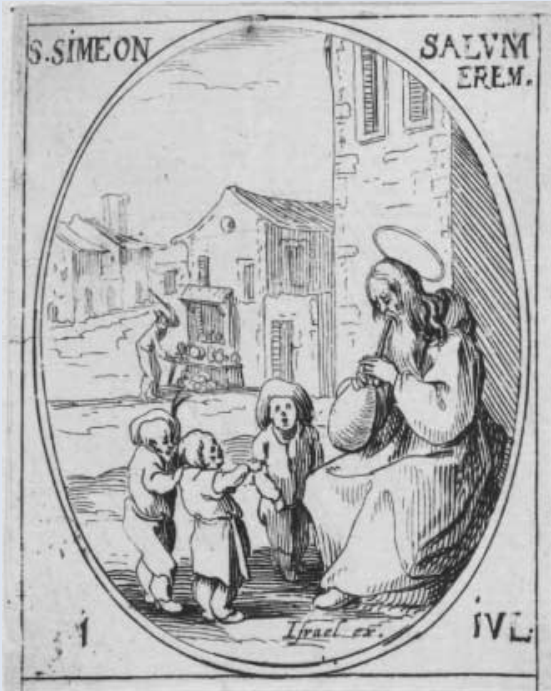

Jacques Callot, Saint Simeon Salus, 17th century. Imaging Department (c) President and Fellows of Harvard College. Reproduced with permission. snuffed the candles and when people ran after him to expel him from the church he pelted women violently with the nuts. Once he was expelled, he overturned the tables of the pastry chefs, and they consequently almost beat him to death.

The life of Symeon contains common features with traditional hagiographical literature with the purpose of showing that the saint was an imitator of Christ. Thus, Symeon gives food to the poor, practises exorcisms and saves people from sins. Nonetheless, he had erratic behaviours unparalleled in other anchorites that constantly provoked public scandals: he ate copiously in taverns, defecated in the streets, practised nudism, entered the baths of women, pretended to rape a woman and walked around being carried and whipped by prostitutes in a sadomasochistic manner. The behaviours described in the life of Symeon could be compatible with severe mental illness, but his reputation made him turn the patron of the mentally ill, whose festivity is celebrated on 1 July. Probably due to the eccentricity of Symeon Salus, there is not an iconographical tradition of him and therefore no devotional images. Calendars are probably the only visual source for Symeon Salus. A 17th-century French calendar illustrates the festivity of 1 July with a beautiful etching by the artist Jacques Callot that lyrically depicts Symeon in the city of Emesa surrounded by children. 